\title{
NILAI TUKAR DAN TRADE FLOWS
}

\section{Siti Astiyah}

\section{Setyawan Santoso ${ }^{1}$}

\begin{abstract}
Abstraksi
The paper is testing the Marshal-Lerner condition and the J-Curve phenomenon on the Indonesian trade. We apply the panel regression model and anlyze the impact of the real depreciation of Rupiah on the trade performance, both in the short run and in the long run.

The study indicates the insignificant of the Rupiah real depreciation to boost the export performance in the short run. When the time horizon is long enough, the increase of the export caused by the depreciation, will offset the increase of the import, hence in the long run the real depreciation of Rupiah may significantly increase the trade performance, but still in a small number.

The implication is clear for the policy maker; if the aim of the policy is to boost the trade performance, then the exchange rate policy should not be an alternative, rather using policy to increase the productivity, efficiency, product quality management, loose tax policy and the creation of the business climate. This includes the industrial re-structuring to lower the import dependences.
\end{abstract}

JEL Classification: C23, F14

Keywords: J-Curve, Marshal-Lerner, trade, exchange rate, panel regression.

\footnotetext{
${ }^{1}$ Penulis adalah peneliti pada Biro Riset Ekonomi Bank Indonesia. Pendapat dalam tulisan ini adalah pendapat pribadi dan tidak harus mewakili pendapat Bank Indonesia.
} 


\section{PENDAHULUAN}

Kebijakan moneter ditransmisikan ke sektor riil melalui beberapa jalur antara lain melalui jalur nilai tukar. Perubahan nilai tukar domestik tersebut akan berpengaruh ke inflasi melalui dua cara. Pertama, secara langsung akan berpengaruh terhadap inflasi melalui barang-barang impor (direct pass-through effect). Kedua, melalui peningkatan daya saing (kompetisi) barang ekspor (indirect pass-through effect). Namun demikian, tingkat kompetisi produk ekspor tentu tidak hanya dipengaruhi oleh perubahan nilai tukar tetapi juga dipengaruhi faktor lain misalkan tingkat efisiensi tenaga kerja, tingkat efisiensi bahan baku, dan proporsi bahan antara impor. Oleh karena itu, perubahan nilai tukar (depresiasi nilai tukar domestik) belum tentu secara otomatis akan meningkatkan net ekspor karena hal ini akan sangat tergantung dari faktor-faktor lain didalam penentuan tingkat kompetisi produk ekspor dan juga struktur industri dari barang ekspor tersebut. Sehubungan dengan hal tersebut, perlu dikaji apakah perubahan nilai tukar akan berpengaruh meningkatkan net ekspor atau justru sebaliknya.

Tujuan studi ini terutama untuk menganalisa pengaruh perubahan nilai tukar terhadap perilaku ekspor dan impor (trade flows) di Indonesia dan untuk menganalisa apakah depresiasi nilai tukar riil akan memperbaiki kinerja trade balance. Studi ini menggunakan data panel. Studi empiris mengenai perilaku ekspor dan impor dengan menggunakan data panel belum banyak dilakukan sehingga hasil studi ini diharapkan dapat mengurangi gap tersebut dan dapat memberikan pengertian dampak perubahan nilai tukar terhadap perilaku ekspor dan impor dengan lebih akurat.

Organisasi penulisan studi ini terdiri dari 4 bab. Bab kedua menganalisa perkembangan ekspor, impor, dan variabel terkait lainnya. Bab ketiga mendiskusikan hasil estimasi. Disamping itu, bab ini juga membahas model yang akan digunakan. Bab terakhir merupakan kesimpulan dan rekomendasi kebijakan. 


\section{KERANGKA TEORITIS}

\subsection{MARSHALL-LERNER CONDITION DAN J-CURVE}

Alfred Marshall dan Abba Lerner menyatakan bahwa depresiasi nilai tukar riil akan meningkatkan kinerja current account apabila volume ekspor dan volume impor elastis terhadap perubahan nilai tukar riil. Dampak perubahan nilai tukar riil terhadap current account dibagi kedalam volume effect dan value effect.

Volume effect adalah dampak perubahan unit output ekspor dan impor akibat dari perubahan nilai tukar riil. Mereka berargumen bahwa nilai volume effect adalah positif karena elastisitas ekspor positif (perubahan permintaan volume ekspor terhadap perubahan nilai tukar riil positif $>0$ ) dan elastisitas impor negatif (perubahan permintaan volume impor terhadap perubahan nilai tukar riil $<0$ ). Sementara, value effect adalah kenaikan nilai impor atas dasar harga domestik akibat dari perubahan nilai tukar riil. Sehingga perubahan current account secara netto dapat menjadi positif atau negatif tergantung pada elastisitas ekspor dan impor. Dengan asumsi kondisi current account balance, depresiasi nilai tukar riil akan mengakibatkan current account menjadi surplus apabila jumlah dari elastisitas ekspor dan impor lebih besar dari 1. Jika kondisi ini terpenuhi maka hal ini disebut dengan Marshall-Lerner condition terpenuhi.

Dalam analisa Marshall-Lerner conditian diasumsikan bahwa neraca jasa $=0$ sehingga current account (CA) sama dengan trade balance. Jika CA dinyatakan dalam unit output domestik maka dapat ditulis sebagai berikut:

$$
\mathrm{CA}(\mathrm{EP} * / \mathrm{P}, \mathrm{Yd})=\mathrm{EX}(\mathrm{EP} * / \mathrm{P})-\mathrm{IM}(\mathrm{EP} * / \mathrm{P}, \mathrm{Yd})
$$

dimana $\mathrm{CA}=$ current account, $\mathrm{EX}=$ ekspor, $\mathrm{IM}=$ impor, $\mathrm{EP} * \mathrm{P}=$ nilai tukar riil, $\mathrm{Yd}=$ pendapatan domestik riil.

Dalam persamaan (1), diasumsikan bahwa pendapatan luar negeri adalah konstan sehingga permintaan ekspor hanya merupakan fungsi dari EP*/P (nilai tukar riil).

Misalkan q sebagai nilai tukar riil $(\mathrm{EP} * / \mathrm{P})$ dan $\mathrm{EX}^{*}$ sebagai domestic import dilihat dari sisi luar negeri, bukan dari sisi domestik, maka:

$$
\begin{aligned}
& \mathrm{q}=\mathrm{EP} * / \mathrm{P} \\
& \mathrm{IM}=\mathrm{q} X \mathrm{EX}^{*}
\end{aligned}
$$


Notasi $\mathrm{EX}^{*}$ digunakan karena domestic import dihitung dalam output luar negeri sehingga akan sama dengan volume ekspor luar negeri ke domestik. Sehingga persamaan (3) merupakan impor dengan harga luar negeri yang dinyatakan dalam harga domestik.

Substitusikan (3) ke (1), sehingga current account (trade balance) dapat ditulis sebagai berikut :

$$
\mathrm{CA}(\mathrm{q}, \mathrm{Yd})=\operatorname{EX}(\mathrm{q})-\mathrm{q} X \mathrm{EX}^{*}(\mathrm{q}, \mathrm{Yd})
$$

Jika $\mathrm{EX}_{\mathrm{q}}$ merepresentasikan dampak dari kenaikan q (depresiasi nilai tukar riil) pada permintaan ekspor dan $\mathrm{EX}^{*}{ }_{\mathrm{q}}$ merepresentasikan dampak dari kenaikan q pada volume impor, maka dapat ditulis:

$$
\begin{aligned}
& \mathrm{EX}_{\mathrm{q}}=\Delta \mathrm{EX} / \Delta \mathrm{q} \ldots \ldots \ldots \ldots \ldots \ldots \ldots \ldots \ldots \ldots \ldots(5), \text { dan } \\
& \mathrm{EX}^{*}{ }_{\mathrm{q}}=\Delta \mathrm{EX}^{*} / \Delta \mathrm{q}
\end{aligned}
$$

dimana $\mathrm{EX}_{\mathrm{q}}>0$, sedangkan $\mathrm{EX}_{\mathrm{q}}<0$

Dengan depresiasi nilai tukar riil maka harga produk dipasar global menjadi lebih murah sehingga daya saing meningkat. Oleh karena itu, depresiasi akan meningkatkan permintaan ekspor sehingga EXq bernilai positif $\left(\mathrm{EX}_{\mathrm{q}}>0\right)$. Sementara itu EX*q bernilai negatif $\left(\mathrm{EX}_{\mathrm{q}}<0\right)$ karena depresiasi nilai tukar riil akan meningkatkan harga barang impor menjadi lebih mahal sehingga barang domestik menjadi relatif lebih murah sehingga meningkatkan daya saing produk domestik di pasar domestik sehingga akan menurunkan permintaan impor dari luar negeri. Berdasarkan persamaan diatas, selanjutnya dapat dianalisa dampak perubahan q terhadap current account (trade balance) dengan menggunakan marshall lerner condition.

Jika superscript ${ }^{1}$ mewakili nilai awal CA dan ${ }^{2}$ mewakili nilai setelah $\mathrm{q}$ berubah, maka $\Delta \mathrm{q}=\mathrm{q}^{2}-\mathrm{q}^{1}$ sehingga dampak dari perubahan nilai tukar riil terhadap current account adalah sbb :

$$
\begin{aligned}
& \Delta C A=\mathrm{CA}^{2}-\mathrm{CA}^{1}=\left(\mathrm{EX}^{2}-\mathrm{q}^{2} \cdot \mathrm{EX}^{*^{2}}\right)-\left(\mathrm{EX}^{1}-\mathrm{q}^{1} \cdot \mathrm{EX}^{* 1}\right) \ldots(7)
\end{aligned}
$$

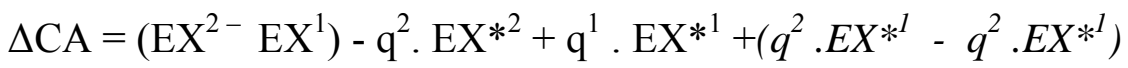

$$
\begin{aligned}
& \Delta \mathrm{CA}=\Delta \mathrm{EX}-\left(\mathrm{q}^{2} \cdot \Delta \mathrm{EX}^{*}\right)-\left(\Delta \mathrm{q} \cdot \mathrm{EX}^{* 1}\right)
\end{aligned}
$$

Dengan membagi sisi kiri dan kanan dengan $\Delta \mathrm{q}$ maka diperoleh reaksi current account terhadap perubahan nilai tukar adalah : 


$$
\Delta \mathrm{CA} / \Delta \mathrm{q}=\mathrm{EX}_{\mathrm{q}}-\left(\mathrm{q}^{2} \cdot \mathrm{EX}_{\mathrm{q}}^{*}\right)-\mathrm{EX}^{* 1}
$$

Dengan demikian maka dampak terhadap current account dibagi kedalam volume effect dan value effect. Besaran $\mathrm{EX}_{\mathrm{q}}$ dan $\mathrm{EX}^{*}{ }_{\mathrm{q}}$ mencerminkan volume effect yaitu dampak perubahan output unit ekspor dan impor akibat dari perubahan q. Nilai volume effect selalu positif karena $\mathrm{EX}_{\mathrm{q}}>0$, dan $\mathrm{EX}_{\mathrm{q}}^{*}<0$. Sementara, $\mathrm{EX}^{* 1}$ mencerminkan value effect dan ini akan negatif memperburuk CA karena dengan meningkatnya nilai tukar riil (q) maka akan meningkatkan nilai impor (pada volume impor semula yang tetap) dalam harga domestik. Selanjutnya, untuk mendapatkan dampak depresiasi nilai tukar riil terhadap CA positif (depresiasi nilai tukar riil memperbaiki CA) maka sisi kanan dari (9) harus positif. Untuk itu kita perlu melihat kembali definisi dari elastisitas ekspor dan impor.

Elastisitas permintaan ekspor dan impor terhadap perubahan nilai tukar riil sebagai berikut:

Elastisitas permintaan ekspor terhadap perubahan nilai tukar riil:

$$
\eta=\left(q^{1} / E^{1}\right) \cdot E_{q}
$$

Elastisitas permintaan impor terhadap perubahan nilai tukar riil

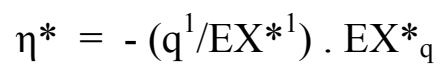

Secara teoritis maka $\eta *$ bertanda minus karena $\mathrm{EX}_{\mathrm{q}}<0$.

Untuk mendapatkan elastisitas, sisi kanan dari persamaan (9) dikalikan dengan $\left(\mathrm{q}^{1 /}\right.$ $\mathrm{EX}^{1}$ ) sehingga persamaan (9) dapat ditulis kembali menjadi:

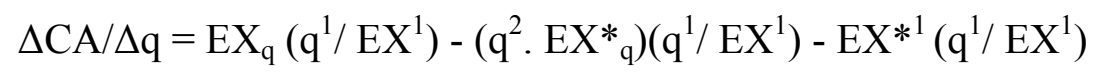

Substitusikan (10) dalam (12) :

$$
\Delta C A / \Delta q=\eta-\left(q^{2} \cdot E^{*}{ }_{q}\right)\left(q^{1 / E X^{1}}\right)-E^{* 1}\left(q^{1 / E X^{1}}\right)
$$

Diketahui bahwa current account pada titik awal dapat dinyatakan :

$$
\mathrm{EX}^{1}=\mathrm{q}^{1} \cdot \mathrm{EX} *^{* 1}
$$

Substitusikan (14) dalam (13) :

$$
\begin{aligned}
\Delta C A / \Delta q & =\eta-\left(q^{2} \cdot E X^{*} q\right)\left(q^{1} / E X^{1}\right)-E X^{1} / E X^{1} \\
& =\eta-\left(q^{2} \cdot E X^{*} q\right)\left(q^{1} / E X^{1}\right)-1
\end{aligned}
$$

Substutusikan (14) dalam (16) : 


$$
\begin{aligned}
\Delta C A / \Delta q & =\eta-\left(q^{2} \cdot E X^{*} q\right)\left(1 / E X^{*}\right)-1 \ldots \\
& =\eta-\left(q^{2} \cdot E X^{*} q\right)\left(1 / E X^{*}\right) \cdot q^{1 / q^{1}-1} \\
& =\eta-\left(q^{2} / q^{1}\right)\left(E X^{*} q\right)\left(q^{1} / E X^{*}\right)-1 \ldots
\end{aligned}
$$

Substitusikan (11) dalam (19):

$$
\Delta \mathrm{CA} / \Delta \mathrm{q}=\eta+\left(\mathrm{q}^{2} / \mathrm{q}^{1}\right) \eta^{*}-1
$$

Untuk mendapatkan $\Delta \mathrm{CA} / \Delta \mathrm{q}$ bernilai positif maka :

$$
\eta+\left(\mathrm{q}^{2} / \mathrm{q}^{1}\right) \eta^{*}-1>0
$$

Jika perubahan q diasumsikan sangat kecil, maka q2 = q1 sehingga perubahan nilai tukar q yang dapat meningkatkan current account terjadi ketika:

$$
\eta+\eta^{*}>1
$$

Menurut Marshall Lerner Condition, depresiasi riil dari suatu mata uang akan meningkatkan kinerja trade balance jika jumlah dari elastisitas (dalam nilai absolute) permintaan impor dan ekspor terhadap nilai tukar riil lebih besar dari $1(>1)$. Sehingga jika persamaan (21) tersebut terpenuhi maka dikatakan bahwa Marshall-Lerner condition terpenuhi.

Akan tetapi, jika jumlah dari elastisitas permintaan impor dan ekspor terhadap nilai tukar riil mendekati $1 \quad(\sim 1)$ maka depresiasi nilai tukar riil tidak akan berpengaruh secara signifikan terhadap current account (trade balance). Penjelasan secara sederhana dapat dipresentasikan dalam kondisi ekstrim berikut (Vanssau(2002)).

\section{Kinerja Ekspor dalam mengoffset kenaikan nilai impor (Elastisitas} impor $=0$ )

Kondisi trade balance tidak berubah:

- Jika $\eta^{*}=0 \rightarrow \eta=1$

- Jika $\eta^{*}<0 \rightarrow \eta<1$ dengan $\eta+\eta^{*}=1$

Kondisi trade balance meningkat (Marshall-Lerner condition terpenuhi: $\eta+$ $\eta *>1)$ :

- Jika $\eta^{*}=0 \rightarrow \eta>1$ 
- Jika $\eta^{*}<0 \rightarrow \eta<1$ asalkan $\eta+\eta^{*}>1$

Jika elastisitas impor $=0$, maka nilai impor (dalam mata uang domestik) akan meningkat sebesar prosentase depresiasi nilai tukar riil. Untuk menjaga kinerja trade balance agar tidak menurun maka nilai ekspor (dalam mata uang domestik) harus meningkat sebesar prosentase kenaikan nilai tukar riil sehingga elastisitas ekspor $=1$. Namun untuk meningkatkan kinerja trade balance, maka nilai ekspor harus meningkat lebih besar dibandingkan dengan kenaikan nilai tukar riil sehingga elastisitas ekspor harus $>1$.

Jika elastisitas impor $\neq 0$ maka kenaikan nilai impor tidak sebesar prosentase depresiasi nilai tukar riil sehingga elastisitas ekspor dapat $\leq 1$ asalkan jumlah dari elastisitas ekspor dan impor $>1$. Oleh karena itu, apabila kondisi jumlah elastisitas ekspor dan impor $\sim 1$ artinya kenaikan nilai impor dioffset sepenuhnya oleh kenaikan nilai ekspor sehingga tidak terjadi perubahan kinerja trade balance.

2. Kinerja impor dalam mengimbangi kemampuan peningkatan nilai ekspor (Elastisitas ekspor $=0$ )

Kondisi trade balance tidak berubah:

- Jika $\eta=0 \rightarrow \eta^{*}=-1$

- Jika $\eta>0 \rightarrow \eta^{*}<-1$ asalkan $\eta+\eta^{*}=1$

- Kondisi trade balance meningkat (Marshall-Lerner condition terpenuhi: $\eta$ $\left.+\eta^{*}>1\right)$ :

- Jika $\eta=0 \rightarrow \eta^{*}>-1^{2}$

- Jika $\eta>0 \rightarrow \eta^{*}<-1$ asalkan $\eta+\eta^{*}>1$

Jika elastisitas ekspor $=0$ maka nilai ekspor (dalam mata uang domestik) tidak berubah sama sekali meskipun terjadi depresiasi nilai tukar riil. Untuk menjaga kinerja trade balance, nilai dari impor (dalam mata uang domestik) harus menurun sama dengan dengan prosentase kenaikan depresiasi nilai tukar riil sehinga elastisitas impor $=1$. Namun untuk meningkatkan kinerja trade

${ }^{2}$ Dalam nilai absolutnya 
balance, maka penurunan nilai impor harus lebih besar dari prosentase depresiasi nilai tukar riil sehingga elastisitas impor $>1$.

Jika elastisitas ekspor $\neq 0$ maka terjadi sedikit peningkatan nilai ekspor sehingga untuk menjaga kinerja trade balance maka elastisitas impor dapat $\leq 1$ asalkan jumlah dari elastisitas ekspor dan impor $>1$. Apabila kondisi jumlah dari elastisitas ekspor dan impor $\sim 1$ artinya peningkatan nilai ekspor sepenuhnya mengoffset kenaikan nilai impor sehingga tidak terjadi perubahan kinerja trade balance.

Elastisitas ekspor dan impor pada dasarnya dapat dilihat dalam jangka pendek dan panjang sehingga analisa Marshall-Lerner condition juga dapat diterapkan untuk jangka pendek dan panjang. Elastisitas ekspor dan impor dalam jangka panjang ini terkait dengan J-curve hypothesis. Menurut J-curve hypothesis, depresiasi nilai tukar riil akan meningkatkan kinerja trade balance sedangkan appresiasi akan menurunkan kinerja trade balance. Namun demikian, terdapat efek tunda dimana setelah terjadinya depresiasi nilai tukar riil maka biasanya trade balance akan memburuk terlebih dahulu dan baru akan membaik setelah beberapa bulan kemudian. Pola pergerakannya mengikuti huruf J sehingga disebut $J$ Curve ${ }^{3}$.

Dalam jangka pendek, terjadinya depresiasi nilai tukar riil akan meningkatkan nilai impor dalam mata uang domestik karena naiknya harga barang impor dalam mata uang domestik. Sedangkan ekspor dalam jangka pendek tidak berubah. Sehingga trade balance menurun.

Dalam jangka panjang, diperkirakan akan terjadi penyesuaian dalam volume impor serta terjadinya peningkatan dalam volume ekspor sejalan dengan semakin kompetitifnya harga ekspor. Sehingga akan meningkatkan kinerja trade balance.

3 Dalam perkembangannya, beberapa penelitian tidak mendukung terjadinya J-curve bahkan menemukan response nilai tukar terhadap trade balance mengikuti pola huruf S sehingga disebut Scurve. Pola S-Curve adalah pola yang tercipta dari perkembangan respon dinamik (dynamic responses) dari nilai tukar terhadap trade balance. Backus 1994, Kehoe dan Kydland (1994) menciptakan suatu model internasional real business cycle dan menemukan bahwa terjadi counter cyclical dan cross correlation dalam trade balance dan terms of trade sehingga menyebabkan perkembangan trade balance mengikuti huruf S. Depresiasi nilai tukar riil dalam jangka pendek akan memburuk, kemudian membaik namun setelah beberapa kuartal kembali cenderung memburuk sehingga responsnya membentuk huruf $\mathrm{S}$. 
Oleh karena itu, dampak depresiasi nilai tukar riil terhadap trade balance terjadi melalui price effect (value effect) dan volume effect. Price effect menyebabkan penurunan kinerja trade balance sedangkan volume effect akan meningkatkan kinerja trade balance. Pola pergerakan dampak depresiasi nilai tukar domestik riil terhadap trade balance ini mirip huruf J sehingga dikenal dengan J-curve.

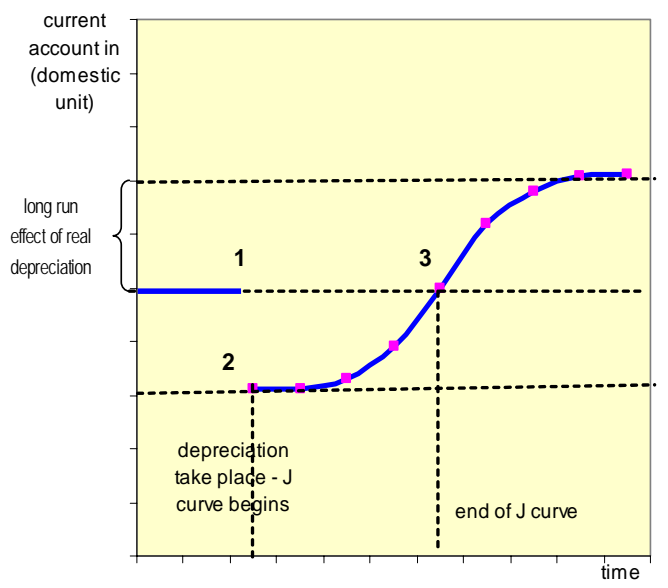

Sumber: Krugman, 2000 p. 467

Penurunan trade balance setelah depresiasi nilai tukar riil disebabkan karena sebagian besar pemesanan ekspor dan impor dilakukan beberapa bulan sebelumnya. Sehingga nilai impor meningkat dalam mata uang domestik. Sementara itu ekspor yang dihitung dalam mata uang domestik tidak meningkat sehingga terjadilah penurunan kinerja trade balance. Bahkan apabila kontrak baru dilakukan dengan nilai tukar baru, dampaknya tidak segera dapat dirasakan karena pelaksanaan pengiriman dan pengapalan ekspor dilakukan beberapa bulan kemudian. Dalam gambar, penurunan tersebut terlihat dari pergerakan point 1 ke point 2 .

Dengan berjalannya waktu maka ada beberapa penyesuaian seperti penyesuaian dari sisi produksi dan juga penyesuaian pembangunan pabrik dan peralatan guna memenuhi permintaan ekspor dari luar negeri. Sementara, impor bahan baku dari luar negeri juga memerlukan waktu penyesuaian. Hasil dari proses ini akan meningkatkan kinerja current account secara bertahap sehingga titik equilibrium bergerak dari 2 ke 3. Pada tahap selanjutnya current account akan meningkat sampai mencapai dampak depresiasi dalam jangka panjang. Dengan kata lain, dalam jangka pendek maka depresiasi nilai tukar riil kemungkinan akan memperburuk current account. Tetapi dengan berjalannya waktu untuk penyesuain maka current account makin membaik secara bertahap sehingga dalam jangka panjang depresiasi nilai tukar 
riil akan meningkatkan kinerja current account. Pergerakan dampak depresiasi nilai tukar riil terhadap current account (lebih tepatnya trade flows) ini mirip huruf-J sehingga secara umum membentuk kurva-J. Sementara, dari beberapa studi mengindikasikan bahwa hasil empiris dampak depresiasi nilai tukar terhadap trade balance dalam bentuk J-curve tidak konklusif.

\subsection{MODEL EKSPOR}

Studi empiris mengenai perilaku ekspor banyak dilakukan dengan beberapa pendekatan ${ }^{4}$. Salah satu pendekatan yang sering dilakukan adalah dengan lebih memfokuskan pada sisi permintaan ekspor. Studi ini juga akan lebih memfokuskan pada permintaan ekspor 5 . Dalam hal ini penawaran ekspor diasumsikan bersifat elastis (supply elasticities are perfectly elastic).

Menurut model standar permintaan ekspor, maka permintaan ekspor akan dipengaruhi oleh berbagai variabel diantaranya harga dari barang itu sendiri, harga barang sejenis dari pesaing, dan pendapatan negara yang dituju (negara importir). Namun demikian, tingkat harga barang itu sendiri juga dipengaruhi oleh berbagai komponen seperti tingkat produktivitas tenaga kerja, produktivitas modal, dan biaya input. Jika permintaan akan barang ekspor tersebut sangat responsive terhadap perubahan harga, maka harga barang sejenis dari pesaing juga kemungkinan akan berpengaruh secara signifikan. Sehingga menurut model standar, fungsi permintaan ekspor dapat ditulis sebagai berikut:

\footnotetext{
${ }^{4}$ Beberapa studi empiris mengenai ekspor dilakukan dengan menggunakan persamaan permintaan dan penawaran ekspor. Dari beberapa studi empiris, persamaan permintaan dan penawaran ekspor tersebut secara umum dapat dituliskan sebagai berikut:

$\mathrm{X}^{\mathrm{s}}=\mathrm{f}\left(\mathrm{P}^{\mathrm{e}}, \mathrm{P}^{\mathrm{d}}, \mathrm{Y}^{\mathrm{d}}\right)$

$\mathrm{X}^{\mathrm{d}}=\mathrm{f}\left(\mathrm{P}^{\mathrm{e}}, \mathrm{P}^{\mathrm{c}}, \mathrm{C}, \mathrm{Y}^{\mathrm{f}}\right)$,

dimana $\mathrm{X}^{\mathrm{d}}, \mathrm{X}^{\mathrm{s}}=$ permintaan dan penawaran (volume) ekspor, $\mathrm{P}^{\mathrm{e}}=$ harga barang ekspor, $\mathrm{P}^{\mathrm{d}}=$ harga barang di pasar domestik, $\mathrm{Y}^{\mathrm{d}}=$ kapasitas utilisasi , $\mathrm{C}=$ kredit, $\mathrm{Y}^{\mathrm{f}}=$ pendapatan luar negeri.

Disamping itu, ada juga studi empiris yang menggunakan persamaan model single reduced form sehingga dalam estimasinya menggunakan persamaan structural dalam bentuk $\mathrm{P}^{\mathrm{e}}$. Dalam model ini berarti permintaan ekspor = penawaran ekspor. Estimasi dengan persamaan single reduced form ini akan menghasilkan elastisitas harga yang cenderung biased downward.

${ }^{5}$ Diasumsikan bahwa penawaran ekspor bersifat elastis karena kapasitas utilisasi di perekonomian domestic kemungkinan masih belum full capacity. Hal ini diindikasikan dengan rata-rata kapasitas utilisasi industri yang relatif masih rendah. Disamping itu, karena fokus dari studi ini untuk menganalisa dampak perubahan dari nilai tukar terhadap trade flows maka permintaan ekspor menjadi lebih relevan.
} 


$$
\mathrm{X}^{\mathrm{d}}{ }_{\text {it }}=\mathrm{f}\left(\mathrm{P}^{\mathrm{x}}{ }_{\text {it }}, \mathrm{Y}_{\text {if }}, \mathrm{P}^{\mathrm{c}}{ }_{\text {it }}\right)
$$

dimana $\mathrm{X}^{\mathrm{d}}{ }_{\text {it }}=$ volume permintaan ekspor i pada periode $\mathrm{t}, \mathrm{P}^{\mathrm{x}}{ }_{\text {it }}=$ harga barang ekspor $\mathrm{i}$ pada periode $\mathrm{t}, \mathrm{Y}_{\mathrm{if}}=$ pendapatan riil tujuan ekspor utama barang $\mathrm{i}, \mathrm{P}^{\mathrm{c}}{ }_{\text {it }}=$ harga barang $\mathrm{i}$ dari negara pesaing pada periode $t$.

Karena adanya keterbatasan data yang tersedia maka harga produk sejenis dari negara pesaing $\left(\mathrm{P}^{\mathrm{c}}{ }_{\text {it }}\right)$ tidak dapat dimasukkan dalam estimasi. Sebagai proksi, studi ini menggunakan variabel REER. Disadari bahwa variabel REER (real effective exchange rates) tidak secara total dapat menggantikan variabel harga barang sejenis dari pesaing karena perhitungan REER menggunakan CPI sehingga memberikan gambaran umum tingkat daya saing eksternal. Sehingga fungsi permintaan ekspor menjadi:

$$
\mathrm{X}_{\text {it }}^{\mathrm{d}}=\mathrm{f}\left(\mathrm{P}_{\text {it, }}^{\mathrm{x}}, \mathrm{Y}_{\text {if, }}, \operatorname{REER}_{\mathrm{t}}\right)
$$

REER digunakan dalam persamaan permintaan ekspor karena REER merupakan salah satu alat ukur untuk mengetahui daya saing produk ekspor dengan mitra dagangnya. Pengukuran REER lebih luas dari BRER (bilateral real exchange rates) ${ }^{6}$, hal ini karena REER telah memperhitungkan set dari mata uang asing dan juga set dari relative prices dari mitra dagang utama. Sehingga variabel REER dapat mengindikasikan daya saing (meskipun jauh lebih umum dibandingkan dengan langsung membandingkan harga produk sejenis dari negara pesaing). Oleh karena itu, REER mengindikasikan daya saing suatu negara terhadap partner dagang utama (relative price competitiveness) yang diukur dengan "kebijakan nilai tukar".

Dalam perhitungan indeks REER yang dilakukan, angka indeks yang meningkat menunjukkan apresiasi nilai tukar rupiah secara riil terhadap mata uang basket currencies, sedangkan penurunan indeks REER menunjukkan depresiasi nilai rupiah. Angka indeks 100 menunjukkan nilai tukar rupiah dalam kondisi netral yang mencerminkan nilai atau daya beli mata uang rupiah relatif sama di Indonesia dan di negara-negara mitra dagang yang mata uangnya termasuk dalam basket currencies. Misalkan REER menurun, berarti nilai tukar nominal terdepresiasi

\footnotetext{
${ }^{6}$ BRER mengindikasikan nilai tukar riil yang telah memperhitungkan harga relatif dari barang-barang di dua negara. Sehingga BRER merupakan salah satu ukuran untuk mengetahui daya saing suatu negara terhadap negara lain.
} 
sehingga nilai rupiah mengalami penurunan, akibatnya daya beli rupiah di negaranegara mitra dagang utama juga menurun. Sehingga harga barang Indonesia di negara mitra dagang menjadi lebih murah sehingga meningkatkan daya saing dari produk tersebut (relative price competitiveness) dan selanjutnya akan meningkatkan permintaan ekspor Indonesia. Oleh karena itu, dihipotesakan bahwa hubungan REER dengan permintaan ekspor adalah negatif. Sementara, permintaan ekspor juga akan dipengaruhi oleh pendapatan dari negara tujuan ekspor (Misalkan Indonesia mengekspor ke USA, maka dihipotesakan bahwa PDB USA akan berpengaruh terhadap permintaan ekspor Indonesia). Dihipotesakan bahwa hubungan antara permintaan ekspor dengan pendapatan negara tujuan adalah positif. Makin tinggi pendapatan negara tujuan ekspor maka makin tinggi permintaan ekspor. Dalam studi ini, data negara tujuan ekspor adalah PDB AS. Sementara, tingkat harga akan berpengaruh negatif terhadap permintaan ekspor. Makin tinggi harga barang makin menurun permintaan ekspor.

Sejalan dengan fungsi standar permintaan ekspor, maka model fungsi permintaan impor adalah sebagai berikut:

$$
\mathrm{M}_{\mathrm{it}}=\mathrm{f}\left(\mathrm{P}^{\mathrm{m}}{ }_{\text {it }}, \text { REER, } \mathrm{Y}_{\mathrm{d}}\right)
$$

dimana $\mathrm{M}_{\mathrm{it}-\mathrm{m}}=$ volume impor $\mathrm{i}$ pada periode $\mathrm{t}, \mathrm{P}^{\mathrm{m}} \mathrm{it}_{\mathrm{t}}=$ harga barang impor $\mathrm{i}$ pada periode $\mathrm{t}, \mathrm{REER}=$ real effective exchange rates, $\mathrm{Y}_{\mathrm{d}}=$ PDB domestik riil.

Permintaan barang impor akan dipengaruhi oleh tingkat harga barang impor, REER, dan 'pendapatan riil domestik' ${ }^{7}$. Makin tinggi tingkat harga barang maka permintaan akan barang impor makin menurun sehingga dihipotesakan bahwa hubungan antara harga barang impor dengan permintaan barang impor adalah negatif. Sedangkan hubungan antara permintaan impor dengan pendapatan riil domestik adalah positif. Makin tinggi pendapatan riil domestik maka permintaan impor makin meningkat. Sementara, kontras dengan ekspor maka hubungan antara REER dengan permintaan impor adalah positif. REER meningkat mengindikasikan nilai tukar mata uang domestik nominal terapresiasi sehingga nilai rupiah mengalami peningkatan daya beli, akibatnya daya beli rupiah meningkat. Sehingga harga barang impor menjadi

\footnotetext{
${ }^{7}$ Untuk kelompok impor barang konsumsi maka regressor yang digunakan adalah konsumsi dan kelompok lainnya menggunakan regressor ekspor plus investasi.
} 
lebih murah di ukur dengan mata uang domestik dan daya saing barang lokal menurun sehingga permintaan akan barang impor meningkat. Oleh karena itu, dihipotesakan bahwa hubungan REER dengan permintaan barang impor adalah positif. 


\section{METODOLOGI DAN DATA}

\subsection{METODOLOGI}

Pengujian hipotesis mengunakan analisis data panel (pooled time series, crosssection data). Keuntungan dari menggunakan data panel antara lain sebagai berikut:

1. Estimasi dengan data panel dapat menunjukkan secara eksplisit setiap heterogenitas kedalam perhitungan menurut keunikan dari variabel individual.

2. Data panel dapat mengatasi masalah yang berkaitan dengan kurangnya data historis yang diperlukan.

3. Jika dibandingkan dengan menggunakan cross section estimation, maka data panel lebih baik karena data panel menggunakan seluruh informasi yang tersedia secara time series dan menggunakan prosedur berbasis cross-section.

Analisis regresi data panel yang akan dilakukan dalam studi ini adalah regresi tertimbang lintas kelompok (cross-section weighted regression) dengan fixed effect intercept estimator. Penggunaan regresi tertimbang dipilih karena residual bersifat heteroskedastis dan tidak berkorelasi contemporaneous secara lintas kelompok industri. Sementara itu estimator fixed effect memungkinkan parameter intercept berbeda antar kelompok barang. Sehingga dengan menggunakan model fixed effects maka intercept bervariasi untuk setiap kelompok barang tetapi tetap mengasumsikan bahwa koefisien slope adalah konstan antar unit cross section:

$$
Y_{\text {it }}=\beta_{1 \mathrm{i}}+\beta_{2} X_{2 i t}+\beta_{3} X_{3 i t}+\varepsilon_{\text {it }}
$$

dimana subscrib i pada intercept menunjukkan bahwa intercept dari setiap unit cross section mungkin berbeda. Perbedaan ini kemungkinan menunjukkan ciri spesifik masing-masing unit cross section. Namun demikian, meskipun intercept mungkin berbeda untuk setiap kelompok barang tetapi tidak bervariasi terhadap waktu dan dalam model ini menggunakan estimator generalized least square (GLS).

\subsection{DATA}

Data ekspor yang akan digunakan adalah ekspor non-migas yang mempunyai peranan sangat besar dalam ekspor Indonesia. Data ekspor mencakup 28 kelompok barang. Untuk impor, hampir semua impor telah dapat dicakup dalam studi ini baik untuk impor barang konsumsi, bahan baku, maupun barang modal. Sedangkan untuk 
data harga barang ekspor dan impor menurut klasifikasi barang, studi ini menggunakan pendekatan bahwa harga merupakan hasil bagi dari nilai dengan volume. Pendekatan ini digunakan karena keterbatasan data yang tersedia, sehingga harga dirumuskan sebagai berikut:

Harga barang ekspor $i=$ nilai ekspor barang $i /$ volume barang ekspor $i$

Data yang digunakan dalam basis bulanan mulai Januari 2002 sampai dengan Maret 2005. Periode sampel dimulai dari 2002 karena adanya perbedaan sistem pencatatan dan coverage (cakupan) dengan periode sebelumnya. Dapat diinformasikan bahwa sejak 2004 telah digunakan sistem pencatatan baru dengan menggunakan sistem on line, sedangkan pada periode sebelumnya menggunakan sistem pencatatan off line. Disamping itu, juga ada perbedaan coverage dimana sejak 2004 menggunakan open file 2 bulan dibandingkan sebelumnya menggunakan open file 3 bulan. Penyesuaian terhadap sistem baru ini telah dilakukan untuk data mulai tahun 2002, sedangkan untuk periode sebelumnya belum dilakukan penyesuian secara formal. Oleh karena itu, studi ini menggunakan periode sampel mulai Januari 2002. Sementara, data PDB tersedia dalam basis triwulanan, untuk merubah menjadi data bulanan digunakan interpolasi.

Untuk mendapatkan gambaran umum tentang kondisi aktual setiap variabel yang terkait dalam proses estimasi, bagian berikutnya akan menjelaskan stylized fact atas kondisi yang ada di Indonesia.

\subsubsection{STYLIZED FACT}

\subsubsection{PERANAN EKSPOR DALAM PEREKONOMIAN INDONESIA}

- Telah terjadi pergeseran penggerak perekonomian Indonesia dari konsumsi menjadi investasi dan ekspor. Hal ini disebabkan karena investasi dan ekspor tumbuh jauh lebih tinggi dibandingkan dengan pertumbuhan konsumsi. 


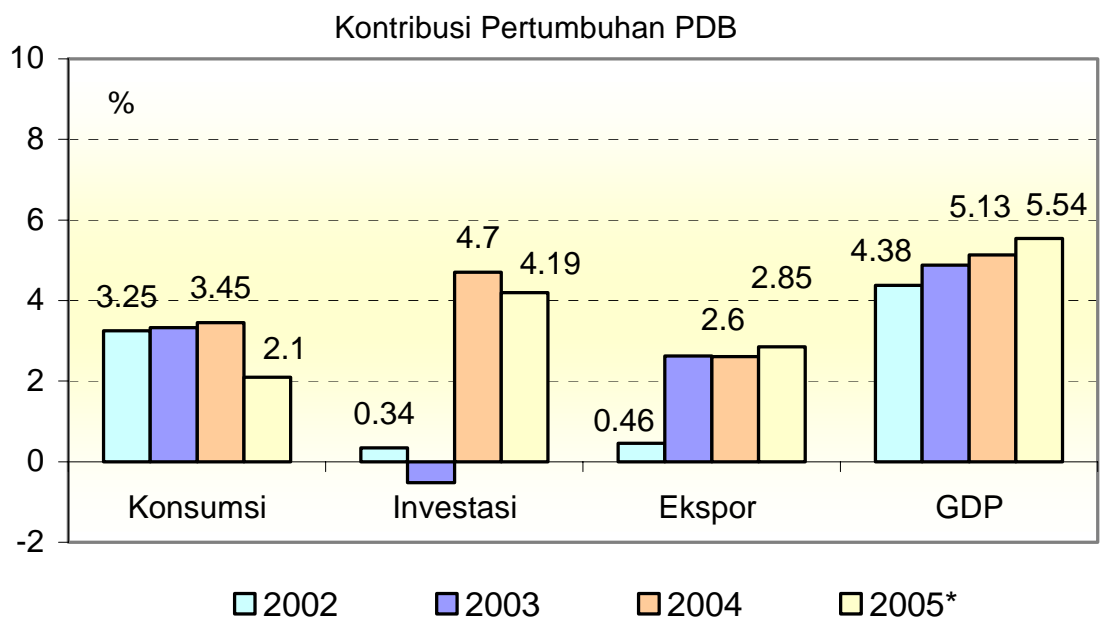

Sumber : BPS
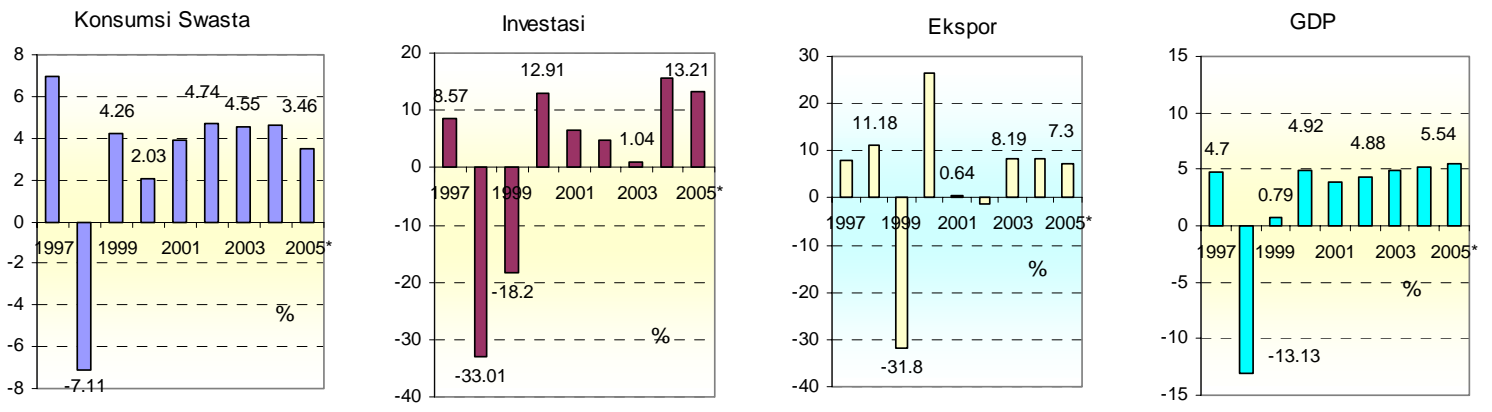

Sumber : BPS

- Dalam triwulan II-2005, investasi dan ekspor merupakan penggerak penting perekonomian. Investasi dan ekspor masing-masing masing memberikan kontribusi pertumbuhan sebesar 4,2\% dan 2,8\% dari pertumbuhan PDB sebesar 5,5\%. Sementara itu peranan konsumsi yang sebelum tahun 2004 selalu menjadi motor penggerak perekonomian, kini hanya memberikan kontribusi sebesar 2,1\%. Adanya pergeseran ini disebabkan oleh pertumbuhan investasi dan ekspor yang relatif tinggi yaitu masing-masing tumbuh sebesar $13,2 \%$ dan 7,3\% pada triwulan II-2005. Sementara itu konsumsi yang sejak 2001 selalu tumbuh di atas 4\%, pada triwulan II-2005 hanya tumbuh sebesar $3,4 \%$. 


\subsubsection{KOMPOSISI EKSPOR DAN DAYA SAING}

\begin{tabular}{|c|c|c|c|c|}
\hline \multirow{2}{*}{\multicolumn{3}{|c|}{$\begin{array}{ll}\text { Share (\%) } \\
\text { I-2004 }\end{array}$}} & \multicolumn{2}{|c|}{ Pertumbuhan (\%) } \\
\hline & & & I-2004 & I-2005 \\
\hline Total Ekspor & 100.0 & 100.0 & 4.5 & 27.5 \\
\hline Migas & 22.9 & 23.3 & 6.5 & 18.7 \\
\hline Minyak Mentah & 9.2 & 9.7 & 10.3 & 21.3 \\
\hline Hasil Minyak & 2.9 & 2.6 & -6.0 & 11.1 \\
\hline Gas & 10.8 & 11.1 & 6.7 & 18.2 \\
\hline Non Migas & 77.1 & 76.7 & 3.9 & 30.2 \\
\hline Pertanian & 4.0 & 3.5 & -8.8 & 35.8 \\
\hline Industri & 66.3 & 68.0 & 7.2 & 23.4 \\
\hline Pertambangan & 6.8 & 5.2 & -20.2 & 15.1 \\
\hline
\end{tabular}

Sumber : BPS

- Komposisi ekspor Indonesia tahun 2005 (semester I) ditandai dengan meningkatnya peranan migas dibandingkan tahun sebelumnya menjadi sebesar $23,3 \%$ dan menurunnya peranan ekspor non migas menjadi sebesar $76,1 \%$. Meningkatnya peranan migas tersebut terjadi akibat dari kenaikan harga minyak. Sedangkan menurunnya peranan non migas terjadi akibat dari penurunan volume perdagangan dunia dan harga komoditi primer beberapa produk (CPO dan batu bara).

- Dari keseluruhan ekspor non migas, ekspor industri pengolahan mempunyai porsi terbesar (84\%), sedangkan pertambangan dan pertanian memegang peranan masing-masing sebesar $11,2 \%$ dan $4,7 \%$ pada semester $1-2005$.

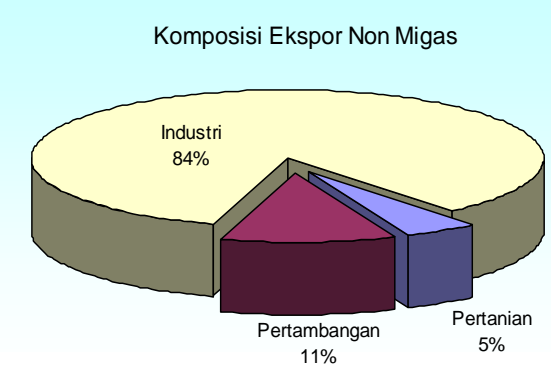

Sumber : BPS Semester I - 2005

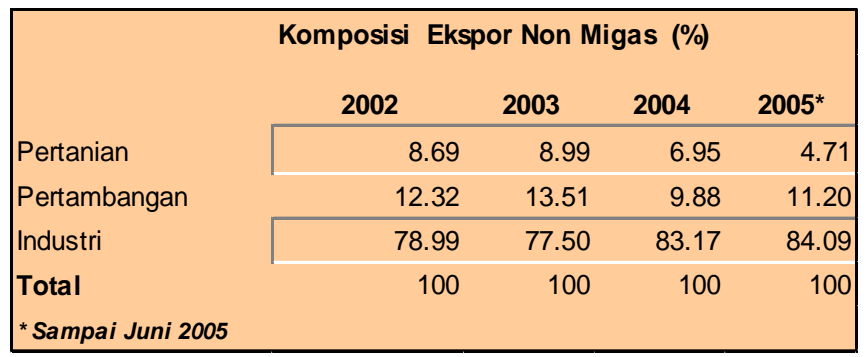

Sumber : BPS 
- Namun demikian, daya saing eksternal sektor industri belum cukup baik. Daya saing eksternal yang diukur dengan RCA (revealed comparative advantage) mengindikasikan bahwa daya saing tertinggi lebih terkait pada natural resource base primary industry. Hal ini kemungkinan terkait dengan produk alam yang melimpah di Indonesia sehingga biayanya relatif lebih rendah (misalkan batubara, karet). Sedangkan sebagian besar produk industri yang inputnya tidak tergantung pada hasil alam Indonesia belum mempunyai tingkat daya saing eksternal yang cukup di pasar dunia.

\begin{tabular}{|lcrr|}
\hline \multicolumn{4}{|c|}{ Revealed Competitive Advantage (RCA) } \\
\hline & 2001 & 2002 & 2003 \\
\hline No. Nama & & & \\
& 27.27 & 27.27 & 44.72 \\
\hline 2 Fatural rubber, latex, etc & 23.13 & 23.13 & 29.39 \\
\hline $\begin{array}{l}\text { 3 Veneers, Plywood improved or } \\
\text { reconstitued wood worked }\end{array}$ & 17.46 & 17.46 & 17.46 \\
\hline 4 Tin & 15.94 & 15.94 & 15.94 \\
\hline 5 Crustaceans Molucs & 12.10 & 12.10 & 12.10 \\
\hline 6 Kakao & 9.62 & 9.62 & 9.62 \\
7 Coal, pulverized or not & 8.65 & 8.65 & 8.07 \\
\hline 8 Copper ores and concentrates & 6.61 & 6.61 & 6.61 \\
\hline 9 Wood manufactures & & & \\
& 5.42 & 5.42 & 5.42 \\
\hline 10 Textile yarn & 4.36 & 4.36 & 4.88 \\
11 Sound recorder of reproducers & & & \\
& & & \\
& 3.46 & 3.46 & 4.73 \\
\hline 12 Footwear & 3.90 & 3.90 & 3.90 \\
\hline 13 Fabrics, woven of man-made fibres & 4.28 & 4.28 & 3.70 \\
\hline 14 Men's coat & 2.80 & 2.80 & 3.36 \\
\hline 15 Womens's coat & 3.80 & 3.80 & 3.03 \\
\hline
\end{tabular}

Sumber : Deperindag, 2004

\begin{tabular}{|c|c|c|c|c|c|c|}
\hline \multicolumn{7}{|c|}{ Ekspor Non Migas Unggulan Indonesia } \\
\hline \multirow[b]{3}{*}{1} & \multirow[b]{3}{*}{ Electric Appliances } & \multicolumn{3}{|c|}{ Share (\%) } & \multicolumn{2}{|c|}{ Growth (\%) } \\
\hline & & 2003 & 2004 & 2005 & 2003 & 2004 \\
\hline & & 16.7 & 14.4 & 15.3 & -0.6 & -4.0 \\
\hline 2 & Textile and Textile Product & 15.3 & 9.4 & 13.4 & 7.1 & -31.5 \\
\hline 3 & Chemical Product & 7.2 & 6.8 & 7.2 & 18.7 & 5.4 \\
\hline 4 & Wood Product & 5.0 & 3.9 & 5.3 & -6.3 & -13.0 \\
\hline 5 & Cooper & 5.6 & 5.1 & 5.5 & 17.3 & 0.9 \\
\hline 6 & papers & 5.1 & 3.6 & 4.8 & 7.7 & -21.3 \\
\hline 7 & Machinery and Mechanic & 4.4 & 3.7 & 4.9 & 4.5 & -5.9 \\
\hline 8 & Coal & 4.5 & 6.0 & 4.9 & 17.9 & 49.3 \\
\hline 9 & Animals and Husbandry Produc & 3.3 & 3.1 & 3.3 & 7.1 & 2.1 \\
\hline 10 & Footwear & 2.5 & 2.3 & 2.3 & 6.0 & 1.2 \\
\hline 11 & Palm Oils & 3.0 & 4.2 & 5.0 & 30.5 & 54.1 \\
\hline & Rubber & 3.1 & 3.9 & 3.4 & 50.4 & 40.2 \\
\hline Tot & & 75.7 & 66.4 & 75.3 & & \\
\hline
\end{tabular}


- Tujuan ekspor masih menunjukkan ketergantungan yang tinggi pada beberapa negara utama yaitu Jepang 15\%, Amerika 14.4\% dan Singapura 11.24\%. Sementara ini ekspor ke Cina dan Malaysia mulai berkembang dengan pangsa masing-masing $5.8 \%$ dan $4.8 \%$.

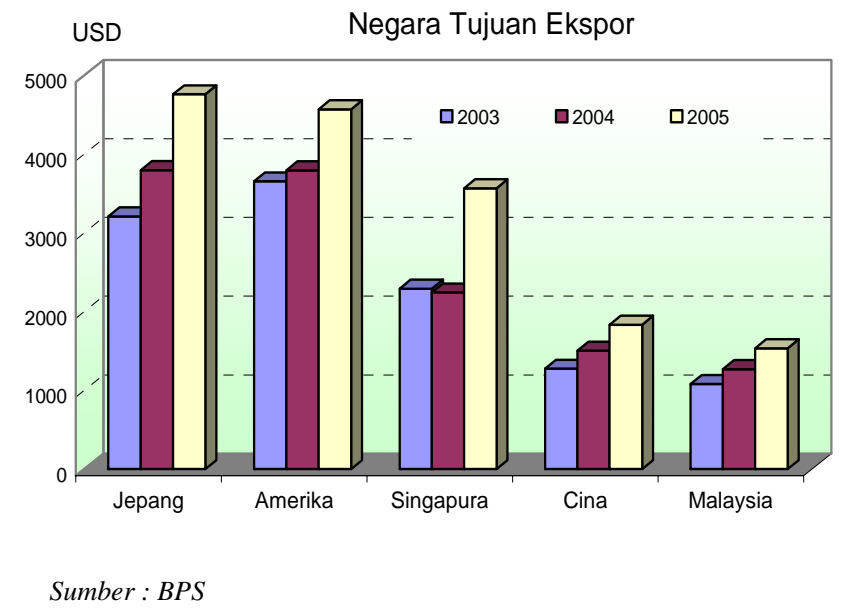

- Sementara, di lihat dari sisi mitra dagang, maka posisi Indonesia relatif belum dominan. Salah satunya mitra dagang yang cukup memperhitungkan posisi Indoneaia adalah Jepang, karena nilai ekspor dari Indonesia menduduki urutan kelima terbesar dengan pangsa 4.3\%. Sementara itu Jepang merupakan tujuan ekspor pertama bagi Indonesia dengan pangsa sebesar 15\%.

- Untuk USA dan China, komoditi ekspor Indonesia ke kedua negara tersebut terkait dengan komoditi primer, food product dan machinery equipment. Indonesia mempunyai daya saing yang cukup baik untuk produk tersebut.

- Untuk Jepang dan Malaysia, peluang ekspor Indonesia masih terbuka khususnya ekspor migas (natural gas-crude oil), raw material, dan furniture. Sampai saat ini posisi Indonesia telah mencapai 4\% dari seluruh impor negara tersebut. 


\subsubsection{FDI (FOREIGN DIRECT INVESTMENT)}

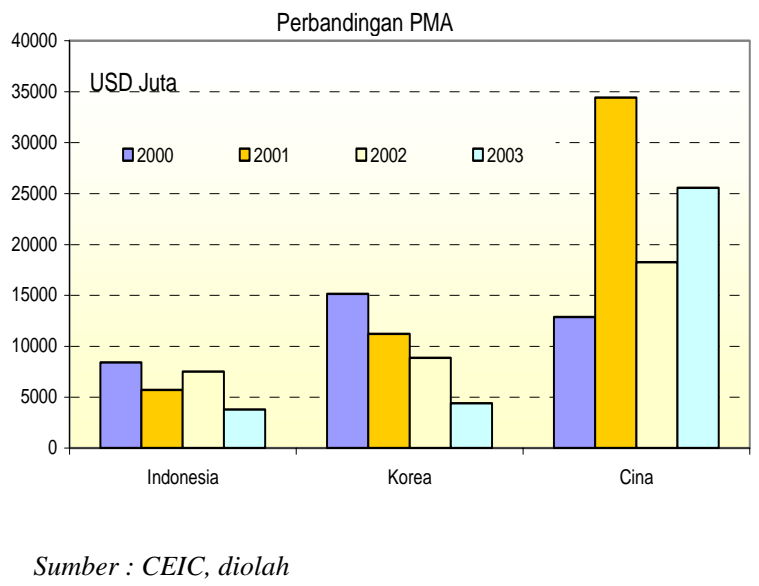

- Penanaman Modal Asing ke Indonesia masih relatif rendah. Realisasi FDI ke Indonesia sampai Juni 2005 sebesar USD 6,6 milyar. Selama ini, angka FDI yang masuk ke Indonesia jauh lebih rendah dibandingkan FDI yang masuk ke negara tetangga seperti Malaysia, Thailand, Korea dan Cina.

- Perkembangan FDI akhir-akhir ini lebih cenderung ke industri yang berorientasi ekspor. Bidang yang diminati oleh FDI adalah kimia-farmasi, konstruksi, industri makanan, transport dan komunikasi, serta industri electronik. Seluruh industri tersebut ditujukan untuk ekspor kecuali industri makanan dan konstruksi.

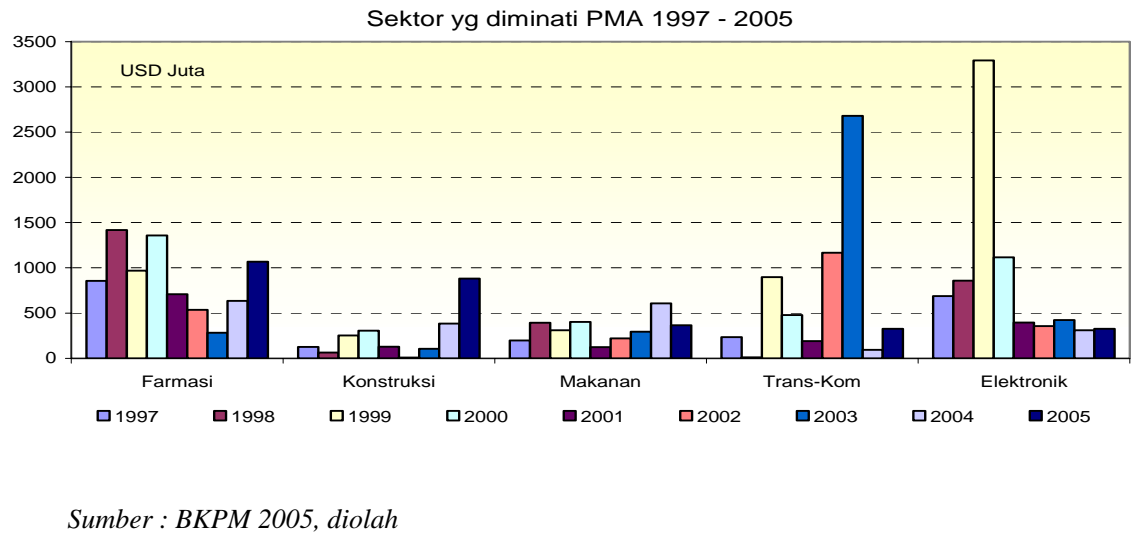

- FDI untuk industri komunikasi mencapai rekor tertinggi pada tahun 2003 dengan investasi yang dilakukan oleh Singtel pada PT Indosat pada bisnis seluler. Sedangkan industri elektronik mencapai puncaknya dengan dibukanya puluhan pabrik elektronik di Batam tahun 1999.

- Negara investor (FDI) terbesar UK, Singapura dan Kanada dengan pangsa masing-masing sebesar $17.5 \%, 9.3 \%$ dan $8.0 \%$. 


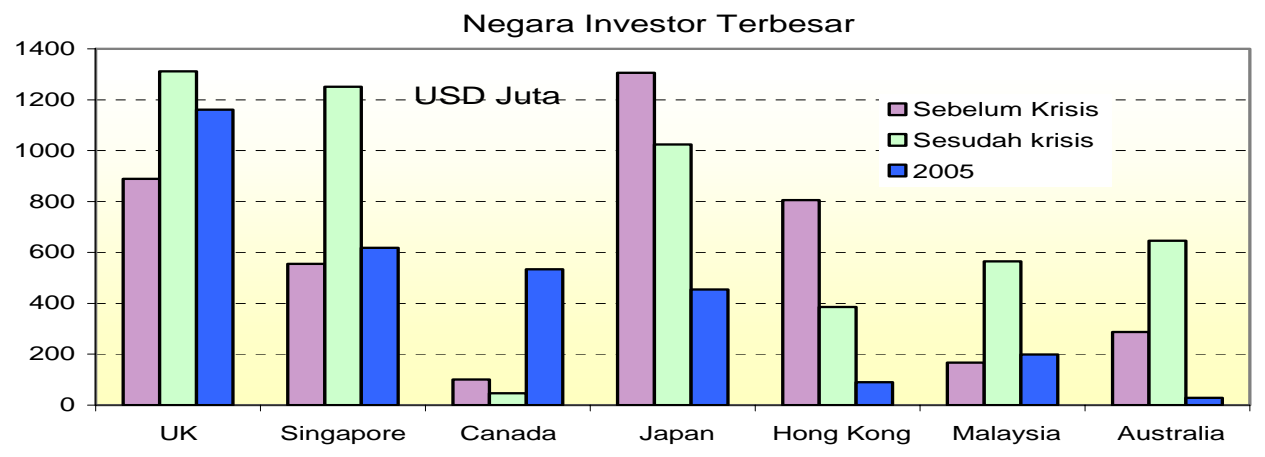

Sumber : CEIC, diolah

\subsubsection{IMPOR}

- Impor Indonesia tahun 2005 didominasi impor bahan baku (76\%) dan barang modal (17\%). Dominasi ini diperkirakan terus meningkat seiring dengan tingginya pertumbuhan investasi.

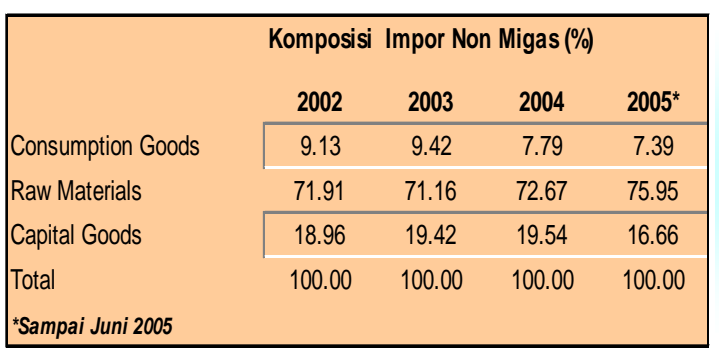

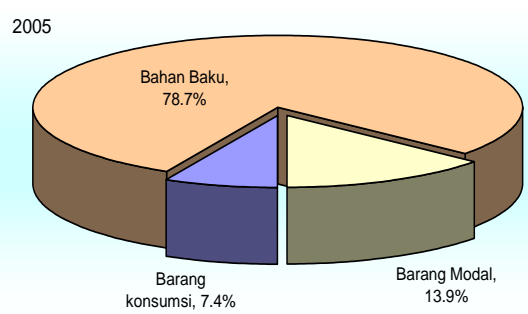

Sumber : BPS

Sumber : BPS

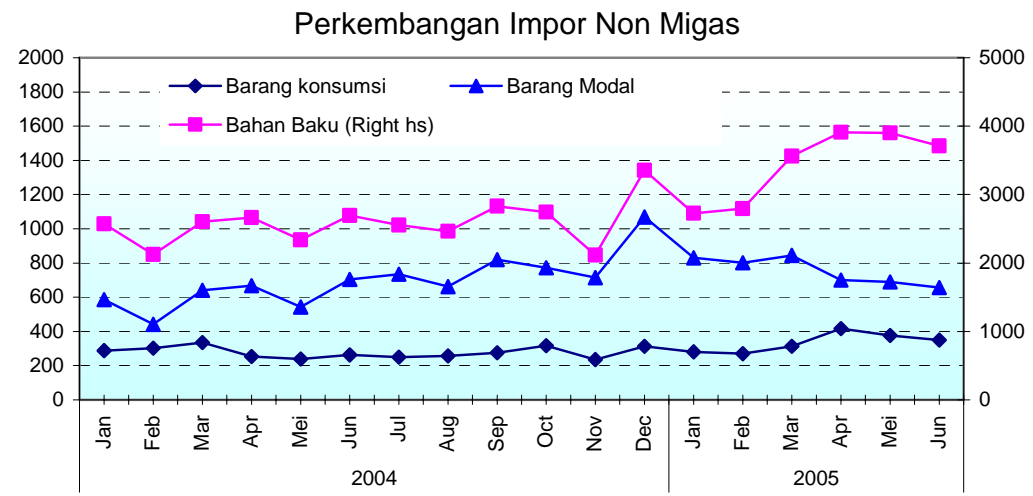

Sumber : BPS 


\subsubsection{NeraCa BerJalan (CURRENT ACCOUnT)}

- Posisi trade balance Indonesia masih menunjukkan angka positif tetapi dengan kecenderungan menurun. Kondisi ini disebabkan oleh tingginya peningkatan impor yang diimbangi dengan kenaikan ekspor yang terbatas.

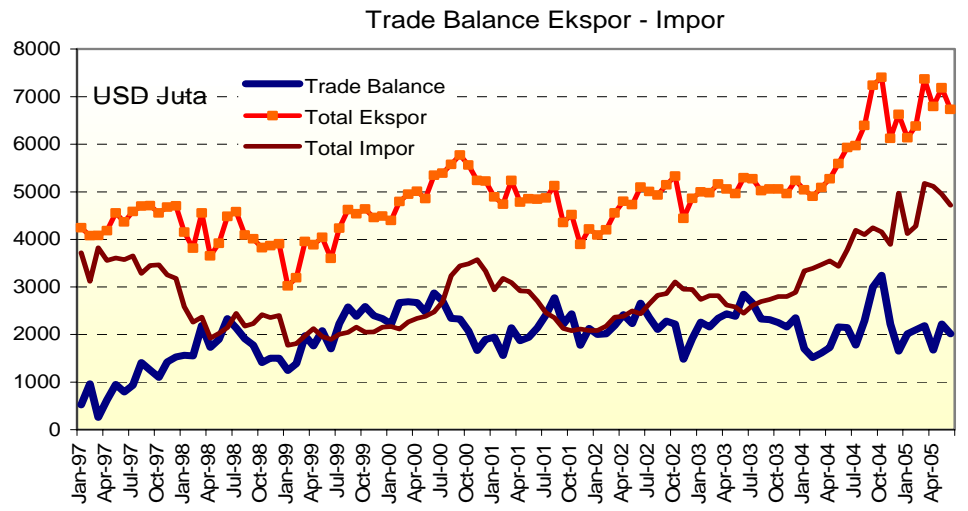

Sumber : Bank Indonesia

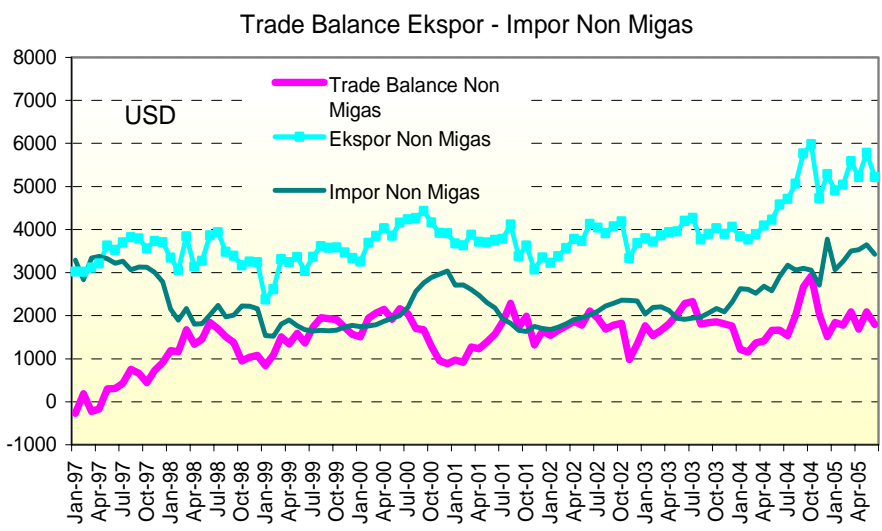

Sumber : Bank Indonesia

- Tingginya impor baik migas maupun non migas dipicu oleh naiknya permintaan domestik baik untuk konsumsi, bahan bakar dan investasi. Sementara terbatasnya pertumbuhan ekspor dipicu oleh kondisi perekonomian dunia, rendahnya RCA dari komoditi andalan serta belum optimalnya ekspor untuk komoditi yang memiliki RCA yang tinggi.

- Meskipun trade balance masih positif, namun current account telah menunjukkan kecenderungan memburuk karena neraca jasa terus-menerus menunjukkan posisi defisit seiring dengan tingginya pembayaran biaya dan bunga. 


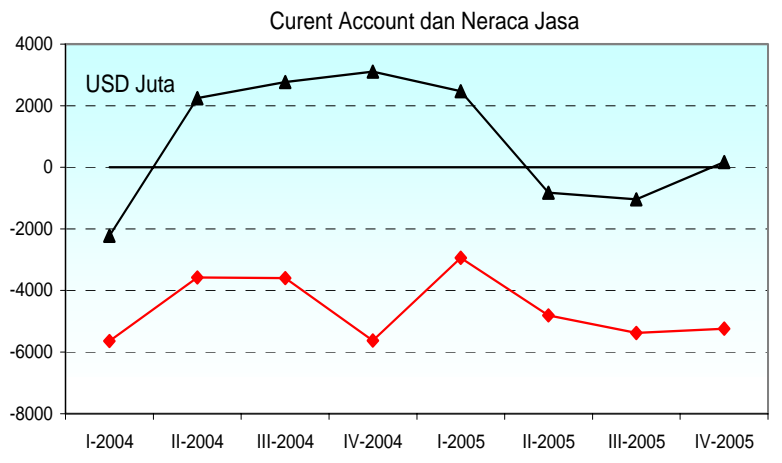

Sumber : Bank Indonesia 


\section{HASIL DAN ANALISIS}

Sesuai dengan tujuan dari studi ini yaitu untuk menganalisa pengaruh perubahan nilai tukar terhadap perilaku ekspor dan impor (trade flows) serta menganalisa apakah depresiasi nilai tukar riil akan memperbaiki kinerja trade balance maka alat analisa dalam studi ini adalah elastisitas ekspor dan impor akibat perubahan nilai tukar riil .

Hasil estimasi permintaan ekspor dipresentasikan dalam Tabel 3.1 berikut:

Tabel 3.1: Ekspor Non-Migas Indonesia

\begin{tabular}{|c|c|c|c|c|}
\hline $\begin{array}{l}\text { Dependent Variable: } \\
\text { Method: GLS (Cross } \\
\text { Date: 07/26/05 Time } \\
\text { Sample: 2002:02 200 } \\
\text { Included observations } \\
\text { Number of cross-sect } \\
\text { Total panel (balanced } \\
\text { Convergence achieve }\end{array}$ & $\begin{array}{l}\text { KSPOR? } \\
\text { ction Weight } \\
1: 06 \\
3 \\
8 \\
\text { is used: } 28 \\
\text { bservations: } \\
\text { after } 12 \text { itera }\end{array}$ & $\begin{array}{l}1064 \\
\text { ons }\end{array}$ & & \\
\hline Variable & Coefficient & Std. Error & t-Statistic & Prob. \\
\hline LP? & -0.70 & 0.03 & -20.08 & 0.00 \\
\hline LREER? & -0.74 & 0.17 & -4.32 & 0.00 \\
\hline LYF? & 1.27 & 0.24 & 5.35 & 0.00 \\
\hline LEKSPOR?(-1) & 0.27 & 0.03 & 10.90 & 0.00 \\
\hline $\begin{array}{l}\text { Fixed Effects } \\
\text {-TIMBER--C } \\
\text { RUBBER--C }\end{array}$ & $\begin{array}{l}0.55 \\
1.44\end{array}$ & & & \\
\hline COFFEE--C & 0.15 & & & \\
\hline -TEA--C & -0.49 & & & \\
\hline _PEPPER--C & -0.83 & & & \\
\hline _TOBACCO--C & -0.05 & & & \\
\hline ANIMALPROD--C & 1.44 & & & \\
\hline -TIN--C & 0.49 & & & \\
\hline _COPPER--C & 1.80 & & & \\
\hline NICKEL--C & 0.07 & & & \\
\hline _ALUMINIUM--C & 0.37 & & & \\
\hline COAL--C & 1.85 & & & \\
\hline _TEXTILE--C & 2.40 & & & \\
\hline HANDICRAFT--C & -0.74 & & & \\
\hline -WOOD--C & 1.79 & & & \\
\hline -RATTAN--C & -0.11 & & & \\
\hline _PALMOIL--C & 1.50 & & & \\
\hline -COPRA--C & -1.65 & & & \\
\hline -CHEMICAL--C & 2.04 & & & \\
\hline METAL--C & 0.46 & & & \\
\hline ELECTRICAL--C & 2.55 & & & \\
\hline -CEMENT--C & -0.26 & & & \\
\hline _PAPERS--C & 1.71 & & & \\
\hline _RUBBERPROD--C & 0.56 & & & \\
\hline -GLASS--C & 0.31 & & & \\
\hline _FOOTWEAR--C & 1.20 & & & \\
\hline -PLASTIC--C & -0.05 & & & \\
\hline -MACHINERY--C & 1.61 & & & \\
\hline R-squared & 0.99 & Mean de & Jendent var & 6.42 \\
\hline Adjusted R-squared & 0.99 & S.D. dep & endent var & 5.04 \\
\hline S.E. of regression & 0.40 & Sum squ & ared resid & 168.11 \\
\hline Log likelihood & -207.69 & F-statist & & 5314.15 \\
\hline Durbin-Watson stat & 1.72 & Prob(F-s & atistic) & 0.00 \\
\hline
\end{tabular}

Tabel 3.1 mengindikasikan bahwa permintaan ekspor dipengaruhi secara signifikan oleh tingkat harga barang, pendapatan luar negeri, dan REER serta dengan arah 
hubungan (tanda) yang konsisten dengan hipotesa. Penurunan harga $1 \%$ akan diikuti dengan kenaikan permintaan volume ekspor $0.7 \%$, dengan kata lain elastisitas harga sebesar 0,7. Permintaan ekspor juga dipengaruhi secara positif oleh pendapatan luar negeri dan bersifat elastis dimana kenaikan pendapatan luar negeri (importir) sebesar $1 \%$ akan meningkatkan permintaan ekspor $1,27 \%$ atau income elasticity lebih besar dari 1.

Pengaruh REER terhadap permintaan ekspor juga signifikan dan dengan tanda sesuai dengan hipotesa dimana depresiasi nilai tukar effektive riil (REER) akan berpengaruh untuk meningkatkan permintaan ekspor. Depresiasi REER sebesar 1\% akan meningkatkan permintaan volume ekspor sebesar 0,74\% atau "Exchange rate elasticity" sebesar 0.74. Hasil studi ini sejalan dengan hasil survei industri yang dilakukan oleh BPS.

Hasil survei BPS mengindikasikan bahwa ditengah trend depresiasi nilai tukar domestik maka secara rata-rata terjadi peningkatan proporsi output dari perusahaan domestik yang dipasarkan ke luar negeri (ekspor). Hal ini mengindikasikan bahwa depresiasi nilai tukar domestik kemungkinan berkontribusi untuk mendorong perusahaan domestik untuk lebih memasarkan outputnya ke pasar global sehingga proporsi penjualan ke luar negeri (ekspor) makin meningkat.

Grafik 3.1: Nilai Tukar dan Rata-rata Proporsi Ekspor terhadap Output

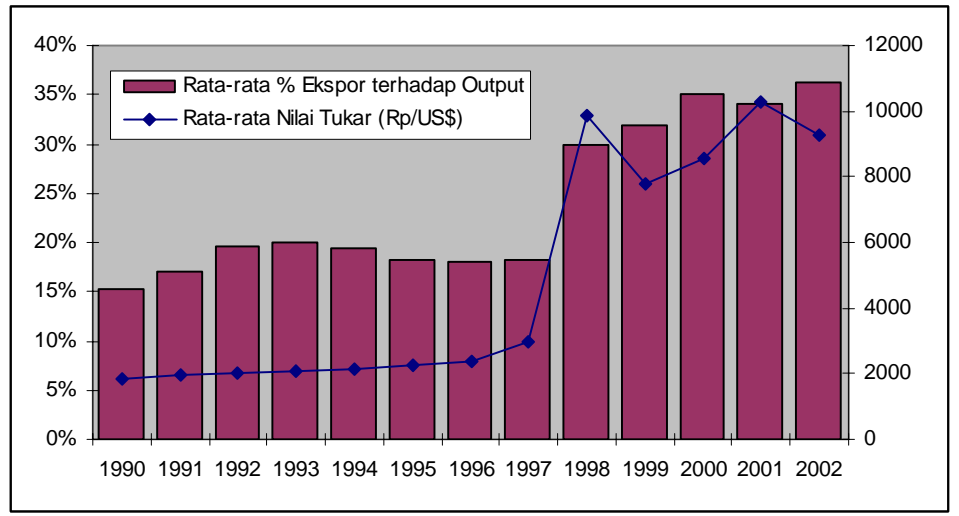

Sumber : BPS, diolah.

Peningkatan ekspor tersebut, kemungkinan juga akan meningkatkan permintaan impor terhadap bahan baku karena cukup besarnya import content dari barang-barang ekspor Indonesia. Data Input-Output 2000 mengindikasikan bahwa import content dari ekspor Indonesia cukup tinggi. Secara rata-rata, import content 
untuk produk ekspor dari sektor industri cukup besar (20,22\%). Sedangkan import content ekspor pertanian dan pertambangan meskipun tidak terlalu besar tetapi proporsi ekspor barang pertanian dan pertambangan juga relatif kecil. Hasil estimasi permintaan impor dipresentasikan dalam Tabel 3.2.

Tabel 3.2: Impor Indonesia

\begin{tabular}{|c|c|c|c|c|}
\hline \multicolumn{5}{|c|}{$\begin{array}{l}\text { Dependent Variable: LIMPOR? } \\
\text { Method: GLS (Cross Section Weights) } \\
\text { Sample: 2002:02 2005:03 } \\
\text { Included observations: } 38 \\
\text { Number of cross-sections used: } 14 \\
\text { Total panel (balanced) observations: } 532 \\
\text { Convergence achieved after } 7 \text { iterations }\end{array}$} \\
\hline Variable & \multicolumn{2}{|c|}{ Coefficient Std. Error } & t-Statistic & Prob. \\
\hline LREER? & -0.61 & 0.38 & -1.59 & 0.11 \\
\hline LREER?(-1) & 0.65 & 0.34 & 1.90 & 0.06 \\
\hline LPM? & -0.91 & 0.04 & -22.53 & 0.00 \\
\hline LYD1? & 1.46 & 0.13 & 11.09 & 0.00 \\
\hline LIMPOR?(-1) & 0.17 & 0.03 & 5.63 & 0.00 \\
\hline $\begin{array}{l}\text { DUMMY220? } \\
\text { Fixed Effects }\end{array}$ & 0.14 & 0.09 & 1.61 & 0.11 \\
\hline SITC112--C & -7.60 & & & \\
\hline SITC122--C & -6.97 & & & \\
\hline SITC322--C & -8.23 & & & \\
\hline SITC610--C & -7.94 & & & \\
\hline SITC620--C & -7.69 & & & \\
\hline SITC630--C & -7.16 & & & \\
\hline SITC111--C & -6.46 & & & \\
\hline SITC121--C & -7.14 & & & \\
\hline SITC210--C & -6.19 & & & \\
\hline SITC220--C & -4.47 & & & \\
\hline SIITC420--C & -5.62 & & & \\
\hline SITC530--C & -5.75 & & & \\
\hline SITC410--C & -5.18 & & & \\
\hline SITC521--C & -7.12 & & & \\
\hline $\bar{R}$-squared & 0.99 & Mean de & ependent va & 5.69 \\
\hline Adjusted R-squared & 0.99 & S.D. dep & Jendent var & 3.11 \\
\hline S.E. of regression & 0.26 & Sum squ & uared resid & 35.61 \\
\hline Log likelihood & 82.54 & F-statist & & 3856.33 \\
\hline Durbin-Watson stat & 1.89 & $\operatorname{Prob}(\mathrm{F}-\mathrm{s}$ & statistic) & 0.00 \\
\hline
\end{tabular}

Hasil estimasi impor menunjukkan bahwa permintaan impor Indonesia dipengaruhi secara signifikan oleh tingkat harga, "pendapatan", dan REER. Tabel 3.2 mengindikasikan bahwa kenaikan harga barang impor sebesar $1 \%$ akan mengakibatkan permintaan akan barang tersebut menurun sebesar 0,91\% atau elastisitas harga dari barang impor sebesar 0,91. Permintaan barang impor juga dipengaruhi oleh "pendapatan" dimana kenaikan "pendapatan" sebesar 1\% akan meningkatkan permintaan barang impor sebesar 1,46\% atau dengan kata lain "income elasticity" $>1$. Disamping itu, hasil estimasi mengindikasikan bahwa hubungan antara REER secara netto dengan permintaan impor bersifat positif yang berarti depresiasi nilai tukar riil akan menurunkan permintaan impor dan sebaliknya. Hubungan positif ini sejalan dengan hipotesa. Meskipun demikian dampak REER secara total terhadap 
impor relatif kecil. Elastisitas "nilai tukar riil" hanya sebesar 0,04 yang berarti jika terjadi depresiasi "nilai tukar riil" (REER) sebesar 1\% maka volume impor akan menurun sebesar $0,04 \%$.

Rendahnya elastisitas impor ini kemungkinan terkait dengan hal berikut. Dengan depresiasi nilai tukar riil maka permintaan ekspor diperkirakan akan meningkat karena makin meningkatnya daya saing produk Indonesia di luar negeri (lihat hasil estimasi permintaan ekspor). Akan tetapi, import content dari produk ekspor tersebut cukup signifikan sehingga depresiasi nilai tukar riil juga akan meningkatkan permintaan impor. Namun demikian, untuk produk yang pemasarannya lebih cenderung ke domestik maka dengan adanya depresiasi nilai tukar riil akan mengurangi daya saing produk mereka sehingga kemungkinan akan berpengaruh ke output akibatnya permintaan bahan baku untuk produk yang pemasaraanya lebih ke pasar domestik akan berkurang. Sehingga disatu sisi depresiasi kemungkinan akan meningkatkan permintaan impor (untuk industri yang export oriented) tetapi disisi lain kemungkinan juga akan mengurangi permintaan impor (untuk industri yang pemasarannya domestic oriented). Sehingga secara netto dampak depresiasi nilai tukar riil terhadap permintaan impor tidak cukup tinggi.

Sementara, dengan dasar teori Marshall-Lerner condition yang telah didiskusikan sebelumnya, maka berdasarkan hasil estimasi menunjukkan bahwa penjumlahan elastisitas ekpor dan impor sebagai respon dari perubahan "nilai tukar riil" (REER) masih kurang dari 1 maka syarat Marshal - Lerner condition tidak terpenuhi di Indonesia untuk periode Januari 2002 - Maret 2005. Sehingga depresiasi nilai tukar riil tidak akan memperbaiki kinerja trade balance dalam jangka pendek. Tidak terpenuhinya kondisi Marshal-Lerner condition dalam jangka pendek tersebut belum tentu bahwa depresiasi nilai tukar riil (dalam hal ini REER) tidak dapat meningkatkan kinerja trade balance terutama untuk jangka panjang. Oleh karena itu, perlu dianalisa lebih lanjut J-curve.

Elastisitas ekspor dan impor pada dasarnya dapat dilihat dalam jangka pendek dan panjang sehingga analisa Marshall-Lerner condition juga dapat diterapkan untuk jangka pendek dan panjang. Elastisitas ekspor dan impor dalam jangka panjang ini terkait dengan J-curve hypothesis. Untuk mengetahui apakah di Indonesia dampak depresiasi nilai tukar riil terhadap trade balance mengikuti pola kurva-J maka perlu menghitung elastisitas jangka panjang. Dari hasil estimasi, maka elastisitas harga, 
pendapatan, dan nilai tukar (REER) dalam jangka panjang dipresentasikan dalam Tabel 3.3.

Tabel 3.3: Elatisitas Harga, Pendapatan, dan REER

\begin{tabular}{|c|cc|cc|}
\hline \multirow{2}{*}{ Elastisitas } & \multicolumn{2}{|c|}{ Jangka Pendek } & \multicolumn{2}{c|}{ Jangka Panjang } \\
\cline { 2 - 5 } & Ekspor & Impor & Ekspor & Impor \\
\hline Harga & $-0,70$ & $-0,91$ & $-0,96$ & -1.09 \\
Pendapatan & 1,27 & 1,46 & 1,74 & 1.76 \\
REER ("Exchange rate elasticity") & $-0,74$ & 0,04 & $-1,02$ & 0.05 \\
\hline
\end{tabular}

Elastisitas "nilai tukar" dalam studi ini merepresentasikan perubahan volume ekspor (dan impor) karena adanya perubahan REER 1\%. Seperti telah didiskusikan sebelumnya bahwa dalam jangka pendek maka depresiasi nilai tukar riil yang diukur dengan depresiasi REER tidak akan meningkatkan performa trade balance karena tidak terpenuhinya Marshall-Lerner condition. Namun demikian, hasil estimasi mengindikasikan bahwa depresiasi nilai tukar riil akan meningkatkan kinerja trade balance dalam jangka panjang secara sangat terbatas karena elastisitas ekspor dan impor dalam jangka panjang hanya sedikit diatas 1 (1.07). sehingga Marshall-Lerner condition terpenuhi untuk jangka panjang. Namun demikian, karena penjumlahan elastisitas ekspor dan impor yang hanya sedikit diatas satu yang terutama disebabkan oleh kenaikan ekspor maka perubahan dari trade balance ini juga sangat terbatas. Dengan kata lain, depresiasi nilai tukar tidak akan berpengaruh secara signifikant terhadap performa trade balance meskipun dalam jangka panjang. 


\section{KESIMPULAN DAN REKOMENDASI}

Ekspor dan investasi mempunyai peranan penting dalam menyumbang pertumbuhan ekonomi Indonesia terakhir ini. Komposisi ekspor non-migas didominasi oleh ekspor sektor industri, tetapi tidak semua sektor industri mempunyai daya saing eksternal yang tinggi. Daya saing eksternal yang diukur dengan RCA mengindikasikan bahwa daya saing tertinggi lebih terkait pada natural resource base primary industry. Hal ini kemungkinan terkait dengan produk alam yang melimpah di Indonesia sehingga biayanya relatif lebih rendah (misalkan batubara, karet). Sedangkan sebagian besar produk industri yang inputnya tidak tergantung pada hasil alam Indonesia belum mempunyai tingkat daya saing eksternal yang cukup di pasar dunia.

Sementara, komposisi impor lebih didominasi oleh bahan baku untuk industri. Dengan makin membaiknya perekonomian maka diperkirakan impor bahan baku (dan impor barang modal) makin meningkat. Meskipun impor barang konsumsi juga meningkat tetapi peningkatannya relatif kecil dibandingkan dengan peningkatan impor bahan baku. Hal ini sejalan dengan struktur industri di Indonesia yang sangat tergantung pada bahan baku impor didalam produksinya. Struktur industri ini akan mempengaruhi dampak perubahan nilai tukar terhadap trade balance.

Hasil estimasi dari studi ini mengindikasikan bahwa nilai tukar riil berpengaruh secara signifikan terhadap permintaan ekspor dan impor. Depresiasi REER 1\% akan meningkatkan permintaan volume ekspor sebesar 0,74\% atau "Exchange rate elasticity" sebesar 0.74. Sedangkan depresiasi REER 1\% akan menurunkan permintaan volume impor secara netto sebesar $0,04 \%$.

Atas dasar hasil estimasi tersebut maka studi ini tidak mendukung adanya Marshall-Lerner condition untuk jangka pendek tetapi untuk jangka panjang nampak adanya Marshall-Lerner condition. Meskipun demikian, pola J - curve nampaknya tidak terlalu kuat. Hal ini karena elastisitas ekspor dan impor dalam jangka panjang hanya sebesar 1,07. Sehingga depresiasi nilai tukar riil tidak akan merubah performa trade balance secara signifikan dalam jangka panjang. Sehingga studi ini menyimpulkan bahwa depresiasi nilai tukar effektif riil (REER) tidak akan memperbaiki kinerja trade balance baik dalam jangka pendek maupun dalam jangka panjang. Dengan kata lain, meskipun REER dapat meningkatkan ekspor tetapi 
peningkatan ekspor tersebut akan digunakan untuk mengoffset peningkatan nilai impor sehingga trade balance tidak dapat meningkat secara signifikan.

Studi ini merekomendasikan bahwa kebijakan untuk meningkatkan trade balance seyogyanya tidak difokuskan melalui kebijakan nilai tukar tetapi lebih ditekankan pada peningkatan faktor lain yang menunjang daya saing misalkan peningkatan produktivitas, efisiensi, kualitas produk, pengurangan pungutan tidak resmi, serta penciptaan iklim usaha yang lebih kondusif melalui berbagai kebijakan termasuk kebijakan moneter dan fiskal. Kenaikan ekspor yang terutama disebabkan oleh faktor "bukan kebijakan nilai tukar" akan meningkatkan kinerja ekspor. Peningkatan ekspor ini tidak akan diikuti dengan kenaikan nilai impor (karena nilai tukar tidak berubah) sehingga trade balance akan meningkat. Disamping itu, untuk lebih memperbaiki kinerja trade balance juga dapat dilakukan melalui perbaikan struktur industri. Dalam jangka panjang, struktur industri diarahkan untuk tidak tergantung pada bahan baku impor sehingga perlunya menciptakan industri penunjang di dalam negeri. 


\section{DAFTAR PUSTAKA}

Bank Indonesia (2004), "Macroeconomic Model of Bank Indonesia”,

Desember.

Bouoiyour, Jamal and Serge REY (2002), "Exchange Rate Regime,

Real Exchange Rate, Trade Flows and Foreign Direct Investment: The case of Morocco", Centre d'Analyse Theorique et de Traitement des donnees economiques, France.

Budiman, Aida S., Nanang H., M.Noor Nugroho, Evie Sylviani (2004),

"Kajian Estimasi Nilai Tukar Riil Indonesia: Sebagai Bagian dari Kajian Jangka Panjang Mengenai Dampak Ekonomi dan Keuangan Global terhadap Neraca Pembayaran Indonesia”, Program Kerja Reguler 2004, DKM-BI.

Cerra, Valerie dan Sweta Chaman Saxena (2002), “An Empirical

Analysis of China's Export Behaviour", IMF Working Paper, No.200, IMF, Washington D.C., November.

Duttagupta, Rupa dan Antonio Apilimbergo (2000), "What Happened

to Asian Exports During the Crisis?", IMF Working Paper, No.200, IMF, Washington D.C., Desember.

Krugman, Paul R. dan Maurice Obstfeld (2000), “International

Economics: Theory and Policy", Addison-Wesley Longman Inc., Fifth edition.

Senhadji, Abdelhak dan Claudio Montenegro (1998), "Time Series

Analysis of Export Demand Equations: A Cross-Country Analysis", IMF Working Paper, No.149, IMF, Washington D.C., Oktober.

Vanssau, Xavier de. (2002), Marshall Lerner Condition.

Zhang, Zhaoyong (1996), "The Exchange Value of Renminbi and

China's Balance of Trade: An Empirical Study", NBER Working Paper, No.5771, September. 
